\title{
FIGURATIVE LANGUAGE IN WILLIAM SHAKESPEARE AND WILLIAM WORDWORDTH'S POEM
}

\author{
${ }^{1}$ Vivi Melaty Ruslida, ${ }^{2}$ Barnabas Sembiring, and ${ }^{3}$ Indah Damayanti \\ ${ }^{1,2,3}$ Bengkulu University-Indonesia \\ E-mail:vvivimelaty11@gmail.com, barnabas.sembiring@yahoo.com ndah_078@yahoo.co.id
}

Received on March, 19th, Revised on June 30th, Published on July, 30th 2019

\begin{abstract}
This study aims to determine the use and meaning of figurative language (majas) in poetry. The sample of this study is ten poems from two different writers of the era, namely Shakespeare and Wordsworth. This research uses a descriptive qualitative method and an objective approach used to analyze data. Figurative language (majas) was analyzed based on theories from Wren and Martin and also analyzed the meaning of each figurative language (majas) that had been discovered. The figurative language (majas) found is presented in tabular form. From the data analysis, all figurative languages (majas) were found in Shakespeare's five poems except Euphemism and Irony. In Wordsworth's poem, all figurative languages (majas) are found except Synecdoche and Irony. From the figurative language (majas) that has been found and from the author's background, it has been concluded that Shakespeare is a Poetic person, he usually uses some beautiful words. Meanwhile, Wordsworth is a Romantic person. He usually talks about love, feelings and even sadness which is always associated with the loss of someone he loves.
\end{abstract}

Keywords: Majas, Poetry, William Shakespeare, William Wordsworth

\begin{abstract}
ABSTRAK
Penelitian ini bertujuan untuk mengetahui penggunaan dan makna dari bahasa kiasan (majas) dalam puisi. Sampel penelitian ini adalah sepuluh puisi dari dua penulis yang berbeda zaman, yaitu Shakespeare dan Wordsworth. Penelitian ini menggunakan metode deskriptif kualitatif dan pendekatan objektif yang digunakan untuk menganalisis data. Bahasa kiasan (majas) dianalisis berdasarkan teori dari Wren dan Martin dan juga dianalisis makna dari setiap bahasa kiasan (majas) yang telah ditemukan. Bahasa kiasan (majas) yang ditemukan disajikan dalam bentuk tabel. Dari analisis data, ditemukan semua bahasa kiasan (majas) di dalam lima puisi oleh Shakespeare kecuali Euphemism dan Irony. Dalam puisi Wordsworth, ditemukan semua bahasa kiasan (majas) kecuali Synecdoche dan Irony. Dari bahasa kiasan (majas) yang telah ditemukan tersebut dan dari latar belakang penulis, telah disimpulkan bahwa Shakespeare adalah orang yang Puitis, ia biasanya menggunakan beberapa kata-kata yang indah. Sedangkan, Wordsworth adalah orang yang Romantis. Dia biasanya berbicara tentang cinta, perasaan dan bahkan kesedihan yang selalu dihubungkan dengan kehilangan seseorang yang dicintainya.
\end{abstract}

Kata Kunci: Majas, Puisi, William Shakespeare, William Wordsworth 


\section{INTRODUCTION}

Literature has its own language style to make the readers interesting. There are many aspect of language of literature that are found in literary works, and one of them is figurative language. Figurative language is language that uses words or expressions with a meaning that is different from the literal interpretation.

According to M.H Abrams (1999:96) "Figurative Language is a conspicuous departure from what users of a language apprehend as the standard meaning of words, or else the standard order of words, in order to achieve some special meaning or effect". Mostly, figurative languages are found in poems, whether it is old and modern poems.

Poetry is any kind of verbal or written language that is structured rhythmically and is meant to tell a story, or express any kind of emotion, idea, or state of being (Bernie Ollila and Joe Jantas, 2006). Beside, William wordsworth in Anita (2013) defined that poetry is the spontaneous overflow of powerful feelings and Poem defines as the shytmetics creation of beauty. Poetry is the most condensed and concentrated form of literature, saying most in fewest number of words. Every poem is to be read for its "message," that this message is "hidden" in the poem. Many poets like to "play" with the sound of language or offer an emotional insight by describing what they see in highly descriptive language.

Poem sometimes is difficult to understand the meaning because very often its language is indirect. Usually, the reader to reading and understand the poem and usually avoids, because it will makes them confuse and needs energy to think hard. Moreover, much of poem has to offer is in the form of hidden meanings by the figurative langauge. Furthermore, for this modern era, the figurative language is forgotten because people more interesting to use modern language like slang than figurative language. From the fact before the researcher interested to do the reseach about figurative language in poem. This research focuses on figurative language used in two different authors and separated by two centuries.

William Shakespeare (1564-1616), an English poet and playwright, is widely considered to be the greatest writer in the English language. The researcher chose five poems by William Shakespeare: "Blow Blow Thou Winter Wind", "Shall I Compare Thee to a Summer's Day", "Dirge”, "A Fairy Song", "A Madrigal". On the other hand, William Wordsworth (1770-1850) is known as an English Poet in 1793 era. The researcher chose the five poems by William Wordsworth : "I Wandered Lonely as a Cloud (The Daffodils)", "Desideria”, 
"Evening on Calais Beach", "My Heart Leaps Up", and "A Complaint". The researcher chose different authors and different period is because the researcher wanted to do a new modification research with two different authors while in the previous time, the previous researchers only did with one author. On the other hand, the researcher wanted to show what figurative language that was used commonly in the different authors and their own language styles.

Based on the background, the problem is further formulated, what were the Figurative language expressions found in the Shakespeare and Wordsworth's poems based on Wren and Martin theory?, what were the implied meanings of the figurative on the poems? And how were the Shakespeare's poems different from Wordsworth's poems?

\section{METHODOLOGY}

The research was designed as a descriptive qualitative study. Similarly, Berg in Muhammad (2014) states that qualitative research "Refers to the meaning, concepts, definition, charateristics, metaphors, symbols, and descriptions of things". According this definition, qualitative research goals for description of the object. The researcher employed descriptive qualitative method because it analyzed the data and then described the finding to answer the research question. This method used to describe the kind of five figurative that found in the poems by William Wordsworth and William Shakespeare, and to analyze the implied meaning of the poems. To support this analysis, the researcher used objective approach. Besides, to valid the data, the researcher helped by Validators. The role of validators was to checked the result. In research procedures, the researcher did some steps. Firstly, the researcher read the poems by William Wordsworth and William Shakespeare's poems. After the reseacher read the poem many times, The researcher identified the figurative based on the poems, then the researcher classified the type of the figurative language that used in the poems. After finish, the researcher analyzed the implied meaning of that figurative language that have been classified before. Then, the reseacher discussed the result with the Validators. At the end, the researcher made the conclusion about the research.

\section{RESULTS AND DISCUSSION}

The first result, based on the research questions is what were the figurative language found in the poems above. The researcher analyzed the five poems of William Shakespeare and five poems of William Wordsworth. The researcher focused 
on finding the figurative language based on Wren and Martin's theory. From the explanation before, the figurative language was divided into 11 kinds, thery are Simile, Metaphore, Personification, Apostrophe, Hyperbole, Synecdoche, Metonymy, Antithesis, Irony, Euphemism, and Rhetorical Question. The reseacher shows the table that present the result of figurative language found.

Tabel 1. The Result of Figurative Language

\begin{tabular}{|l|c|l|c|}
\hline \multicolumn{2}{|c|}{ Shakespeare } & \multicolumn{2}{c|}{ Wordsworth } \\
\hline \multicolumn{1}{|c|}{ Figurative } & $\begin{array}{c}\text { Freq } \\
\text { uen- } \\
\text { cy }\end{array}$ & \multicolumn{1}{|c|}{$\begin{array}{c}\text { Figurative } \\
\text { Language }\end{array}$} & $\begin{array}{c}\text { Freq } \\
\text { uen- } \\
\text { cy }\end{array}$ \\
\hline Simile & 8 & Simile & 1 \\
Personification & 8 & Personification & 14 \\
Metaphor & 9 & Metaphor & 0 \\
Antithesis & 5 & Antithesis & 1 \\
Metonymy & 2 & Metonymy & 3 \\
Hyperbole & 7 & Hyperbole & 19 \\
Synecdoche & 2 & Synecdoche & 0 \\
Euphemism & 0 & Euphemism & 1 \\
Rhetorical Q & 2 & Rhetorical Q & 5 \\
Apostrophe & 13 & Apostrophe & 1 \\
Irony & 0 & Irony & 0 \\
\hline
\end{tabular}

In Shakespeare's poems, the researcher found Simile, Personification, Metaphor, Antithesis, Metonymy, Hyperbole, Synecdoche, Rhetorical question and Apostrophe. The first poem, the researcher found Apostrophe, simile, synecdoche, personification, and antithesisi. The example of apostrophe can be seen in the first poem "Blow Blow Thou Winter Wind" that there is an apostrophe from the tittle, and it might give an idea that the poem talks about the condition of winter, but the truth is the poem talks about someone ingratitude more hurting than winter wind. The second poem is "Shall I Compare Thee to a Summer's day, the reseacher found figurative language used in the poem are Metaphor, Metonymy, Hyperbole, Synecdoche, and Rhetorical question. The example of metaphor can be seen in the title, it is comparing "thee" and "summer's day". Shakespeare wanted to show that "the lover" is beautiful than anything, even summer. Historically, the theme of summertime has always been used to evoke a certain amount of beauty, summer also is a growing period. The third poem is "Dirge", the reseacher found figurative language used in the poem are Personification, Hyperbole, Rhetorical question, and Apostrophe. From the poem, shakespeare wanted to show that the character in the poem had killed by a cruel mad and go to die soon. The fourth poem is "A Fairy Song", the reseacher found figurative language used in the poem are Simile, Personification, Antithesis and Hyperbole. This poem talks about a fairy tale, the character flew everywhere to spread the 
dew drops for serve the fairy queen. The last poem is "A Madrigal". In this poem, the reseacher found figurative language used in the poem are Simile, Metaphor and Apostrophe. Besides, this poem talks about the comparison between young and old. How strong the youth and how weak the old people.

Furthermore, the five poems by William Wordsworth are also full of figurative languages. It can be seen from the first poem, "I Wandered Lonely as A Cloud". The reseacher found figurative language used in the poem are Simile, Personification, Metonymy and Hyperbole. In this poem, Wordsworth talked about someone who was lonely and amazed about the golden daffodils. The second poem; "Desideria", the reseacher found figurative language used in the poem are Antithesis, Metonymy, Hyperbole, Euphemism, and Rhetorical question. In this poem, Wordsworth wanted to tell someone who passed away, someone who was loved by the character, and there was no spirit anymore without her. The third one is "Evening on Calais Beach". From the analysis, the reseacher found figurative language used in the poem are Personification, Hyperbole and Apostrophe. In this poem, Wordsworth wrote the character wanted to give the advice to the child who walk beside him that always worship and close to the God, but before, Wordsworth begins with talk about the beautiful scene. The fourth poem is "My Heart Leaps Up", the reseacher found figurative language used in the poem are Personification and Hyperbole. The meaning of the poem is that the child is the father of the man. In other words, our adult selves still contain the kernel of our childhood selves. He wants his days to be, it seems like the days of a child, filled with and tied together by a reverence for nature. The last poem by Wordsworth is " $\mathrm{A}$ Complaint", the reseacher found figurative language used in the poem are Personification, Hyperbole and Rhetorical question. In this poem, Wordsworth wanted to show that he have nothing because he lost someone whom he loved so much. There is no spirit anymore but his love will be forever for her.

From the meaning and figurative language used in the poems from the different author, the reseacher found the differences. Actually the differences between two authors above decided by the dominant of figurative language used, another factor is by the historical of the authors because usually the author write something related to their period.

As the explanation of the figurative language, from the shakespeare's poems, the most figurative language used were 
Apostrophe and Metaphor. Based on the dominant figurative language in Shakespeare, the researcher concluded that it seems that Shakespeare is a Poetic and dramatic person. It can be seen from the way he comparing the lover to the things or nature such as summer's day, winter wind, etc. It can be seen from the poems, he talk to the winter wind, to the corpse, etc. Furthermore, Shakespeare's word choice was influenced by his experience as an author and drama player. It can be seen from the word choice, for example in poem "Blow, blow, thou winter wind" he talk to the winter wind, bitter sky,etc. It seems like he did some monologue. Shakespeare used dramatic language style that can be proved by the historical of Shakespeare and the period of his life. Beside, Shakespeare with the club theater always held on theater show, he showed his drama, comedy, etc. Because he was known as a drama writter, for example Romeo and Juliet, Twelfth Night,etc. So, from the fact above, the reseacher found the reason why is shakespeare language style is dramatic and poetic, and there is no complaint or he wrote something about war because his era was peaceful and there was no war.

Comparing with Shakespeare, William Wordsworth lived in the next 2 century, it called in Romanticism period. So, from the romantiscm period, it gave influenced to the poem. It seems that Wordsworth is a romantic person. It can been from the way he always talked about love, emotion, and everything was related to the feeling. Even the poorness is because the lost of the lover. Besides, the reseacher concluded from the most figurative language used by Wordsworth were Hyperbole and Personification. It can be seen from the word choice used to talked about love and emotion with exaggeration for example his love is never dry. Also he always drew how beautiful of nature, it seems that he loved nature very much so he wrote the beauty of nature as "the golden daffodils" and in the poem "evening on calais beach". Moreover, when he talked about someone whom he loved but she passed away, it can be seen the romantic word from the way he drew how his love was expressed to her. He drew her like the "best treasure" and his love will be forever to her.

Not all figurative language above is found in the poems. From the figurative language based on Wren and Martin, the reseacher did not find Irony. Irony is the figure of speech which is talking about allusion. From the explanation above, irony is not found because of the two authors above are poetic and romantic, so they did not use some words about allusion, as we know that allusion will make someone can hurt. 
Moreover, in Shakespeare's poems, there was no Euphemism but was found in Wordsworth. It is because in Renaissance, people just started to learn so it seems that there was no symbol word in Shakespeare period. On the other hand, in Wordsworth's poem there is no metaphor, synecdoche, and irony. Based on the background of Wordsworth, he was a romatic person so it seems that he did not use some comparing sentences unless it was comparing to the nature or something beauty, but it must be simile because of the used of comparison word "as" or like.

\section{DISCUSSION}

Related to figurative language, there had been many researchers analyzing it. Rudy Tri Pambudi (2016) Department Of English Education School Of Teacher Training And Education Muhammadiyah University Of Surakarta. The tittle is "Figurative Language Used In Robert Frost's Poems". The result of the research are the types of figurative language that found are personification, symbol, metaphor, hyperbole, irony, and apostrophe. And the top figurative used is pesonification. The top implied meaning used is connotative meaning. Another Research done by Jefry Novrian (2016), Department of English Education and Teacher training University of Bengkulu 2016. The tittle is "A descriptive analysis on figurative language in Khalil Gibran Madman's poems" The result is the researcher concluded that the figurative language used in each line and stanza of the poems, they are Personification, Repetition, Hyperbole, Metaphor, Symbolsm, Repetition, Metonymy, Simile, Litotes, Pleonasm. In "Become a Madman" the kinds of figurative language applied are personification, repetition, symbolism. The second poems that is "The eye" the writer found two kinds of figurative language that are personification and rhetorical. The third poem is "Night and the Madman" the writer found simile, hyperbole, personification, metaphor. The fourth are litotes, personification, symbolism, metaphor, hyperbole, pleonasm. The last poem is "The fox" the writer found only metaphor in all lines. Then, Research done by Puspa Sari (2015), Department of English Education and teacher training University of Lakidende, 2015. The tittle is "Penggunaan Metapora dalam Puisi William Wordsworth". The tittle of poems are England I, England II, England III, England IV, and England V. The researcher concluded that Metaphor image as antromorphic are 8 words (42\%), Metaphor image as animal are 6 words (32\%), Metaphor image abstract to concrete are 3 words (16\%), Metaphor image as sinestesia 2 words (11\%). Another Research done by Ginanjar (2015) Departement of English 
Education and teacher training University of Bengkulu 2015. The tittle is "Figurative Language in Broken Wings by Khahlil Gibran: A Pragmatic Perpestive". The result was found 70 sentences of figurative language, with dominant simile 57\% and another kinds of figurative language is Personification, Metaphor, Hyperbole, and Litotes. The last, Research done by Setiawan (2013) Department of English Education and Teacher Training University of Bengkulu 2013. The tittle is "Figurative Language Analysis in Song Lyrics of Cold Play Band". He found out that the most kind of figurative language used in the song were Methapor (80\%), Simile (4\%), Hyperbole (7\%), Personification (7\%), Onomatopoeia (2\%).

\section{CONCLUSION}

After reading and analyzing the five poems by William Shakespeare and William Wordsworth, the reseacher wants to present the conclusion from the discussion above. The reseacher concludes that there are many kinds of figurative language. From all the poems, the reseacher found 10 figurative language in the poems. In Shakespeare's poems, the researcher found Simile, Personification, Metaphor, Antithesis, Metonymy, Hyperbole, Synecdoche, Rhetorical question and Apostrophe. In Wordsworth' poems, The researcher found
Simile, Personification, Antithesis, Metonymy, Hyperbole, Euphemism, Rhetorical question and Apostrophe.

From the figurative language used by two authors above, the reseacher found the differences. In Shakespeare's poem, the dominant of figurative language found were Apostrophe and Metaphor. It seems that Shakespeare was a poetic and dramatic person because from he was a playwright. On the other hand, Wordsworth was a Romantic person because from the figurative language he used hyperbole and personification. Furthermore, he lived in romantic era. From the figurative language used by two different authors above, the researcher did not find Irony.

\section{SUGGESTION}

The reseacher would like give some suggestions related to the case, a) for students in English Department who want to learn subjects : Introduction to Literature and Prose and Poetry, it will help them in classifying and analyzing the poem, b) for the further researcher who wants to take the research about figurative language in poetry, it can be used as references, and c) in general, reading poem can build our vocabulary, which is one of the parts in the English language aspect. 


\section{REFERENCES}

Suryani, T. Anita. 2013. An AnalysisOf Wole Soyinka's Poems: Figurative Language Cases. Jombang: Sekolah Tinggi Keguruan Dan Ilmu Pendidikan Persatuan Guru Republik Indonesia. Journal. (thesis)

Abrams, M, H.1971. Glossary of literature term. New York, Holt, Rinehart and Winson, Inc.

Aminuddin. 2010. Pengantar Apresiasi Karya Sastra. Bandung: Sinar Baru algesindo.

Siswantoro. 2014. Model Pembelajaran. Sastra Inggris untuk SMA Teori dan Praktik. Yogyakarta: Graha Ilmu.

Patel, M. Chirag. 2014. Imagery and

Figurative Language in Wordsworth's poems "The World is too much with us" and "My Heart Leaps up". International Journal of Research (IJR), vol 1, pp 650-654.

Pambudi, Tri Rudi. 2016. Figurative

Language Used in Robert Frost's Poems. Surakarta: Universitas Muhammadiyah Surakarta. (thesis)

Novrian, Jefry. 2016. A Descriptive Analysis on Figurative Language in Khalil Ghibran Madman's Poems. Bengkulu: Universitas Bengkulu (thesis)

Ollila, Bernie., Joe Jantas. 2006. The

$$
\text { definition of Poetry. (paper) }
$$

Wallidain, Birrul. 2012. Figurative

Language in Rupert Brooke's Poems. Salatiga: STAIN Salatiga

Keraf, Gorys. 1985. Diksi dan Gaya Bahasa. Jakarta: PT. Gramedia

Sari, Puspa. 2015. Penggunaan Metapora dalam Puisi William Wordsworth. Lakidende: Universitas Lakidende (thesis)

Miller, James. 1985. Traditions in

Literature. Scott Foreman and Company

Semi, M. Atar. 1988. Anatomi Sastra. Bandung: Angkasa Raya.

Perrine, Laurence, and Thomas R. ARP. 1992. Sound and sense: An introduction to poetry. Eight Edition. London: Southern Methodist University.

Barnwell, Katherine. 1980. Introduction to

Semantic and Translation. Horsley

Abrams, M,H. "Expostulation and Reply." The Norton Anthology of English Literature. Ed.. Vol. 2. New York: W. W. Norton \& Company. 134135.

Margono, 2010. Metodologi Penelitian Pendidikan. Jakarta: Rineka Cipta

Muhammad. 2011. Paradigma Kualitatif Penelitian Bahasa. Yogyakarta: Liebe Book Press. 
Muhammad. 2014. Metode Penelitian

Bahasa. Yogyakarta: Ar-ruz media.

Baldick, Chris. 2001. The Concise Oxford

Dictionary of Literary Terms. New

york: Oxford University Press Inc.

My english page. 2016. William

Shakespeare Short Biography.

Retrieved from

http://www.myenglishpages.com/site_p

hp_files/reading-william-shakespeare-

short- biography.php. Accessed on

January, 22017.

Academy of American Poets. Poet William

Wordsworth. Retrieved from

https://www.poets.org/poetsorg/poet/wi

lliam-wordsworth. Accessed on

January, 22017

Poetry-archieve. 2002. Poems by William

Wordsworth. Retrieved from

http://www.poetry-

archive.com/w/wordsworth_william.ht

ml. Accessed on January, 22017.

Poemhunter.com. William Shakespeare's

Poems. $\quad$ Retrieved from

http://www.poemhunter.com/william-

shakespeare/. Accessed on January, 2

2017. 